\title{
\#sosfavelas: Digital Representations of Violence and Inequality in Rio de Janeiro
}

\author{
Margit $\Upsilon_{\text {stanes }}$
}

\section{INTRODUCTION}

...They said he was a criminal, but yet another innocent died, here we have workers and students, but for them, if you are up on the hill, you are a trafficker. ${ }^{1}$

The above quote was published on the Facebook page of Coletivo Papo Reto (the Straight Talk Collective), a Rio de Janeiro independent journalism collective in February 2015. A few days earlier, Diego Algavez, a 24-year-old motorbike taxi driver was killed by the military police in the Penha complex of favelas. The presence of the military police in Rio's favelas is part of the policy introduced to secure the city before the 2014 FIFA World Cup and the 2016 Olympics. The aftermath of Algavez' murder was covered in real time by Coletivo Papo Reto and Jornal a Nova Democracia, a Rio-based independent newspaper. One of the photos Jornal a Nova Democracia published on their Facebook site shows Algavez' dead body stretched out over his motorbike, on a busy street, in bright sunlight. He is face up, his hips and legs on top of his toppled motorbike.

M. Ystanes $(\bowtie)$

University of Bergen, Bergen, Norway

(C) The Author(s) 2018

M. Ystanes, I.Å. Strønen (eds.), The Social Life of Economic

Inequalities in Contemporary Latin America, Approaches to Social

Inequality and Difference, DOI 10.1007/978-3-319-61536-3_4 
His head and arms are extended behind him towards the ground, which is marked by the blood seeping from his mortal gun wound. Heavily armed policemen dressed in black guard the scene, while people crowd around.

Rio de Janeiro has a serious problem with police violence. In fact, the Rio de Janeiro Military Police has been identified as the force that most kill civilians worldwide (Gaffney 2014). The epigraph above refers to how victims of police violence are very often accused of being involved in drug trafficking-both by the police themselves and in media narratives. However, those killed by the police often turn out to be innocent bystanders, hit by stray bullets, or simply wrongfully targeted. There have even been incidents of small children killed by stray bullets while inside their homes. Therefore, the narrative often promoted by the police and mass media, speculating about victims' potential association with drug trafficking, in many cases both holds little credibility and is inflammatory.

This is especially the case for those who live in self-built neighbourhoods, or favelas, where police violence is mostly located. This situation is reflected in the above reference to being "up on the hill" (no morro, in Portuguese); "for them, if you are up on the hill, you are a trafficker". In Rio de Janeiro, morro, or hill, is often used as a synonym for favela, as many of the city's numerous self-built neighbourhoods are established on the hillsides surrounding the centre and the famous beach areas. The idea that "if you are up on the hill, you are a trafficker" refers to the strong association between favela territories and organised crime in the social imaginary. The force of this imagery obscures the fact that most favela residents are ordinary citizens, workers and students.

The epigraph to this chapter appeared as a caption to a drawing by the artist Carlos Latuff, illustrating the experience of state violence amongst Rio's favela residents. ${ }^{2}$ It depicts a young boy in front of a favela rising on the hill in the background. A wall and barbed wire separate the favela from the formal neighbourhoods outside it. There, a paraglider flies above the famous Sugar Loaf mountain cable car and the skyscrapers of Rio's financial centre-places of leisure and business where favela residents are "undesired". In the version of the drawing that appeared in the Facebook post, a graffiti painted on the wall had been added that read \#soscomplexodoalemao. This refers to the origins of Coletivo Papo Reto in the Alemão complex of favelas, which is near the Penha complex where Diego Algavez was killed. The young boy in the foreground is depicted as a stereotypical favela kid: dark skinned, curly dark hair, shirtless and clutching a football under his arm. The football, of course, connotes both the Brazilian passion 
for the game, as well as the relationship between the FIFA World Cup and experience of state violence. A white-skinned man holding a gun to the boy's head from outside the wall has "state" written across the bottom of his suit's jacket. His head is cut off from the image, and as such he is anonymised. Yet, the depiction of a fair complexion on the hands pointing the gun, as well as the suit, gives some cues about his class and "racial" identity. In the background, a helicopter surveils the favela territory. The overall message of this post is that Rio's favelas and the people who live there are considered as external to the rest of Brazil, and a threat to, not included in, the narrative of Rio as an attractive "global city". Deep-seated inequalities are inscribed in the city's landscape, as illustrated by the physical barrier, the violent state and the surveillance helicopter. By incorporating all these elements, Coletivo Papo Reto's Facebook post illustrates various processes of violence and inequality being played out in Rio de Janeiro at the time: mega-event preparations, the militarisation of informal neighbourhoods, state violence, the "racial" component of class inequality, spatial separation, the vulnerability of unprotected bodies in the face of heavy weaponry and the protest against and documentation of these processes in social media.

Notably, these processes which reflect and grow out of deep-seated inequalities, happened at the height of Brazil's engagement with the Pink Tide. At the time, Brazil had received considerable praise for its ability to combine massive economic growth with reduction in poverty and inequality. In 2012, the country overtook the UK's former position as the world's sixth largest economy (Inman 2012), and 67 per cent of Brazilians considered themselves to be better off than their parents (Olsen 2012). When Brazil was awarded the 2016 Olympics in 2009, the country's middle class had grown by a population the size of California during the previous decade (Barbassa 2015, xiv). Awarding the games to Rio was considered "an unprecedented vote of confidence, a gold star to show that this forever-emerging nation had finally arrived" (Barbassa 2015, xv). However, the preparations for the Games, as well as the 2014 FIFA World Cup, would lay bare that inequality and old power structures continued to work in the Brazilian society (see also Costa (Chap. 3), Sørbøe (Chap. 5), this volume). In fact, the effort to use sporting mega-events to showcase the successes of the Pink Tide governments gave rise to numerous contradictions and an intensification of neoliberal approaches to securitisation as well as the access to urban land. 
One of the traditional markers of inequality in Latin America is that of access to land. Struggles over different kinds of land, urban as well as rural, remain an aspect of contemporary struggles against inequality (Ystanes 2014; Ystanes 2016b; see Brown (Chap. 11), Sørbøe (Chap. 5), this volume, as well as Ng'weno 2007; Sawyer 2003; Rolnik 2015). Indeed, it is an aspect of inequality that Pink Tide economic policies did not significantly address. This chapter explores one particular configuration of this inequality; the struggle over access to, and militarisation of, urban spaces. In Rio de Janeiro, this struggle has profoundly marked its history. Urban development has to a large extent centred on removing the poor from attractive, centrally located areas, and making these areas available to the middle and upper classes (Pearlman 2010; de Magalhães 2013). After the introduction of democracy in Brazil in 1985, favela removals were rarer because of their association with military regimes of the past. However, policies intended to "reclaim" favela territories were reintroduced as the city prepared to host the recent mega-events (see e.g. Barbassa 2015; Larkins 2015; Ystanes 2016b; Rolnik 2015; Savell 2014; Salem 2016; de Magalhães 2013). This "reclaiming" consists of multifaceted processes involving mechanisms such as forced removals, rent inflation, gentrification and militarisation. The anti-mega event activism analysed in this chapter, speaks to these processes of exclusion and socio-spatial segregation. Inspired by Nancy Fraser (1990), I argue that such contestation constitutes a subaltern counterpublic. This counterpublic is born out of, challenges and testifies to the many shortcomings of the Pink Tide in terms of addressing entrenched inequalities in Brazil. In particular, it illustrates that such inequalities remain inscribed in Rio de Janeiro's urban landscape, despite the strides made towards reducing them in the last couple of decades.

\section{Protesting the 2014 FiFA World Cup: Activism-As- JOURNALISM ARISES IN Rio's FAVELAS}

Many of the processes that reproduce inequality in Rio are tied in with a particular agenda for urban and economic development: the hosting of the 2014 FIFA World Cup and the 2016 Olympics. The preparations for these events complicated, and to some extent reversed, the overall project of reducing poverty and inequality. As this chapter illustrates, access to and the use of urban spaces became increasingly a privilege for better-off residents. Furthermore, the public provision of health and education went 
into crisis as funds were divested towards the events in the middle of a recession. This situation was the focus of critique and protests in the period between the FIFA Confederations Cup in 2013 and the 2016 Olympics. In Rio, cariocas, as locals call themselves, gathered regularly under the slogan Não vai ter Copa! (There will be no World Cup!) during the year leading up the 2014 event. These rallies were mostly made up by middle-class protesters who marched in the city centre and sometimes in the Copacabana beach neighbourhood, where the FIFA Fanfest was to be located.

At the same time, a number of alternative media outlets and activist collectives, such as the Coletivo Papo Reto, arose in Rio's favelas. Most of these are based in specific local communities. This sense of belonging is reflected in their names, such as Ocupa Alemão, Jornal Alemão Noticias, Maré Vive, Rocinba em Foco and Voz da Comunidade. ${ }^{3}$ All of these collectives and news services use social media as their main platform of communication, primarily Facebook, Twitter, Instagram, Whatsapp, YouTube and blogs. The flow of communication goes both ways, with readers and followers alerting the collectives to news and sharing photos and updates that are distributed further. In addition, the activist collectives produce their own journalistic material, as well as short films that dramatise events and experiences. They also organise marches and events in their favela communities.

One of the main concerns of these activist collectives is to share information related to experiences of inequality and violence. In particular, they speak of racism and the new forms of violence and exclusion that have arisen from the mega-event security policies introduced in 2008 to subdue drug trafficking organisations in Rio's favelas. In an interview with one of the Coletivo Papo Reto members, he characterised the Não vai ter Copa approach as "a middle class discourse", too radical and with potential for provoking violent clashes. Instead, he explained, the Coletivo protested by emphasising that in its current form, the World Cup was "not for them". Facebook posts such as the one discussed above, and the coverage of events such as the murder of Diego Algavez by the military police, contain powerful, elaborate and painful messages about how, for favela residents, insecurity and exclusion is reinforced rather than reduced through the mega-event-related security policy.

This form of protest, which grows out of deep-felt experiences of exclusion and inequality, has made a far more durable impact on Rio's public spheres of deliberation than the street protest. Street protests are "one-off" 
events, and the messages protesters intend to communicate (e.g. "we want FIFA standard hospitals and schools") are often mixed up with facile slogans such as "Fuck FIFA" or interrupted by police violence against the demonstrators. Furthermore, after the surge during the 2013 Confederations Cup, the protests attracted relatively low numbers of people, thus leaving the impression that discontent with the mega-events is a rather marginal phenomenon. In addition, police violence against protesters and the pre-emptive arrest of several activists prior to a planned march on the day of the World Cup final in 2014 (Deak 2014; Nunes 2014; Brito 2014; Tsavkko Garcia 2014), did much to deter street rallies. In contrast, the messages produced by favela residents and posted on social media, are numerous, constant, concrete and rich in their detail about the problems they experience due to Rio's hosting of mega-events. Crucially, they cannot easily be stopped or censored by authorities. Of course, the long-term outcomes of these developments remain to be seen. Nevertheless, I argue that a methodology and an infrastructure for protest and activism based on social media and mobile technology is one of the most significant legacies of Rio's sporting mega-events. I will come back to this more in detail below.

\section{ACTIVISM-AS-Journalism AND SubaLTERN Counterpublics}

Most of the groups participating in this effort refer to themselves as community news services; they represent a form of alternative journalism. This conception of activism-as-journalism builds upon a long tradition in Latin America, where in particular the radio has been put to subversive use during times of oppression and civil wars, and as a corrective to mass media censorship. The Mexican Canal Seis de Julio, which started producing alternative video documentaries in 1989, first in VHS format and later digitally through their website and YouTube channel, is a case in point. Brazil may be a particularly fertile ground for the contemporary configurations of such activism, as its residents are amongst the world's most eager users of social media (Glenny 2016, 157).

The development of alternative, digital news services such as Coletivo Papo Reto contributes to diversifying the public sphere and challenging the state of affairs they critique. It is also testament to the persistent inequalities in Brazilian society. It is useful to explore the unfolding of these digital narratives in light of Nancy Fraser's critique of Jürgen 
Habermas' notion of the bourgeois public sphere (Fraser 1990). While Habermas' classic text (1991) favours a single public sphere of deliberation, ${ }^{4}$ Fraser argues that this is unrealistic, as numerous subtle mechanisms of exclusions exist, even when formal exclusions are eliminated. People do not leave behind their social positions as they enter the public sphere of deliberation, and their unequal statuses profoundly impact on what is supposed to be a debate between equals. This is of course particularly so in stratified societies. Fraser therefore argues that "in such societies, full parity of participation in public debate and deliberation is not within the reach of possibility" $(1990,66)$. This point is very much in line with the findings of anthropologists who have studied arenas of debate between unequally positioned participants (Caldeira 1988; Green 2003; Sawyer 2003; Ystanes 2011, 2014). Fraser maintains that "arrangements that accommodate contestation among a plurality of competing publics better promote the ideal of participatory parity than does a single, comprehensive, overarching public" $(1990,66)$.

The kind of digital community journalism Coletivo Papo Reto represents is a relatively new phenomenon and it is of course difficult to assess its significance with any kind of certainty as it unfolds. Indeed, Castells $(2015, x)$ points out that networked social movements are often met with scepticism as to their tangible outcomes. Nevertheless, Castells goes on to suggest that the Internet is now such an integrated aspect of our existence that it does not make much sense to consider the virtual a segregated world. As such, it does not make sense either to distinguish between social media activism and real life activism. Activists I spoke to in Rio expressed similar views. Furthermore, social media activism has already contributed to producing tangible results with regards to forced evictions (Ystanes 2016a) and in the launching of the Nós por Nós phone app, specifically designed to help citizens report police violence without risks to their safety (Coelho 2016) (Photo 4.1).

Furthermore, using the Internet to widen the arenas for deliberation and the sharing of information holds value in and of itself. In Brazil, the relevance of this is heightened as the public sphere is infamously dominated by the Globo Media Group. It is of course difficult to quantify the influence held by this corporation in defining the terms of public debate. What is clear, however, is that the market position of their outlets is unique, both in terms of broadcast media and print media. Through their numerous entertainment shows, soap operas, debate programmes and news broadcasts, Globo has unmatched influence over what makes its way to the public 


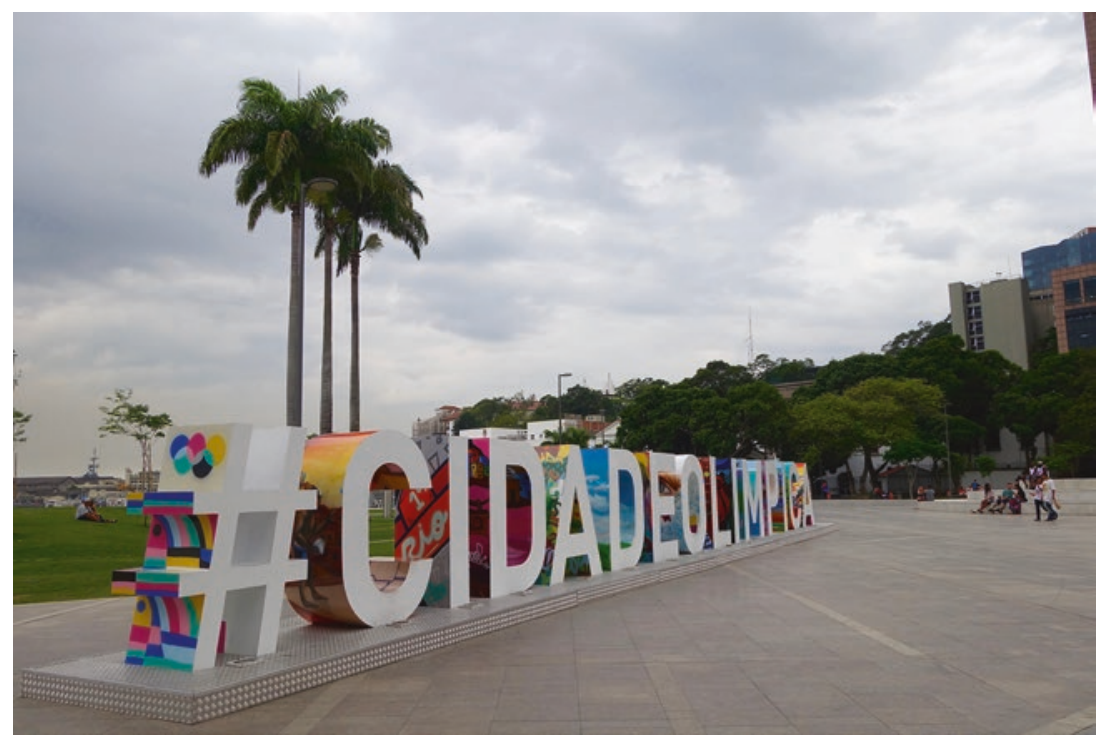

Photo 4.1 Interconnected worlds: as Rio prepared to host the 2016 Olympics, the hashtag \#cidadeolympica, used by the city administration for propaganda purposes, was inscribed onto the urban landscape as a physical manifestation of the interconnection between the virtual and "real life" (Photo: Margit Ystanes)

via mass media outlets. Globo supported the military dictatorship from 1964 to 1985 , something that continues to fuel suspicion among its critics. Today, the tendency for both news and entertainment to portray the perspectives of elites and authorities means that many favela residents perceive there to be no mass media outlet that represent their reality (see also Sørbøe's (Chap. 5), this volume). Social media based activism-as-journalism must be understood as a response to this situation, and as an attempt to create an alternative public sphere. As I will discuss below, the outcome of this effort is tangible, yet still not readily noticeable in the Brazilian mass media dominated public sphere.

\section{Mega-Events, Security and Urban Development}

As mentioned above, mega-events come with their own agenda for economic and social development. Indeed, hosting mega-events involve some of the most expensive, complex and transformative processes that 
cities and nations undertake (Gaffney 2010, 7-8). These events are so complex and large-scale, affecting so many aspects of social and political life, that they may provoke societal opposition on a broad range of issues (Cornelissen 2012, 333). It is expected that mega-events function as vehicles for "accelerated development". This generally involves making public money available for private profit creation, suspending a number of democratic processes, militarising public space and restructuring urban space in the image of global capital (Gaffney 2010,8). These features of mega-event hosting are often thought of as recent developments, but in fact have been part and parcel of Olympic events since their reinvention in the late nineteenth century (Boykoff 2016).

The preparation for mega-events thus impacts on a number of societal processes, as has also been the case in Rio. The city has hosted numerous big events in recent years; the 2007 Pan American Games, 2013 FIFA Confederations Cup, the 2014 FIFA World Cup and the 2016 Olympics. This has led to further erosion of "already fragile democratic institutions, instituting a permanent state of exception" (Gaffney 2014). It is therefore not surprising that mega-events may become the focal points of struggles that extend far beyond the actual events themselves (Cornelissen 2012, $330)$. In Rio de Janeiro, the adaptation of the city for investments and tourism has been met with opposition from a number of social movements and activist networks (see also Sørbøe (Chap. 5), this volume). The protesters have criticised the insufficient investments in the public sector, the transfer of public funds towards event-related infrastructure, tax exemptions for event sponsors, as well as the racism and exclusionary thinking underlying certain event-related policies. As indicated above, the security policy introduced to make the city secure for tourists and investors has been highly controversial.

This relates to Rio de Janeiro's reputation for being a dangerous and violent city. An important aspect of Rio's preparations for the 2014 World Cup and the 2016 Olympics has therefore been to increase public security. This security problem is most strongly associated with the drug trafficking gangs operating out of many of the city's approximately 1000 favelas. According to the 2010 census, about 22 per cent of Rio's inhabitants live in favelas. These informal neighbourhoods have been developing since the nineteenth century as veteran soldiers, freed slaves and migrants settled in Rio's hillsides and outskirts. Today, favelas are expressions of continued socio-economic and "racial" inequality. The enduring impact of colonial slavery can be observed in the overrepresentation of Afro-Brazilians 
amongst the poor, most of whom live in favelas (although far from all favela residents are poor). Because of a historically constituted conceptual link between poverty, dark skin colour, stigma and criminality (Stepan 1991), these informal neighbourhoods have always been considered problematic by the city's political elite. Throughout Rio's history, urban development efforts have therefore often aimed to clear out favelas in the city centre and the famous beach neighbourhoods, and to move the poor to other, less attractive sites (Pearlman 2010; de Magalhães 2013).

Since the early 1980s, rivalling drug trafficking gangs have taken control over several favelas, thus reinforcing their association with danger and violence. Although most people living in favelas are ordinary workers, in the minds of many, they are intrinsically associated with the criminal activity going on there. This association is so strong that the words pobre (poor), preto (black), favelado (favela resident) and bandido (criminal) sometimes function as synonyms. A recent expression of this stigmatising association is a study in which 47 per cent of the interviewees, from 150 Brazilian cities, say they would not like to hire domestic workers who live in favelas. Sixty-nine per cent say they feel afraid when walking past a favela, and 51 per cent associate the word favela with drugs and violence (Brasil 2015). Hence, in the effort to enhance public security before the mega-events, expelling drug traffickers from favelas has been a priority. This is especially so in the favelas near the south zone beaches, near event infrastructure and near the airport. The policy, called pacificação (pacification), centres on the reconquering of favela territories on behalf of the Brazilian state. The army has moved into Rio's favelas one by one since 2008, on preannounced dates. With tanks and heavily armed soldiers, remaining traffickers are forced out or arrested, before permanent military police units called Unidades de Polícia Pacificadora (UPPs) are established.

Many non-favela residents consider the "pacification" policy a success and feel that Rio has become safer because of it. In their experience, the violence that used to spill over from the favelas and onto the "asphalt", as the formal neighbourhoods are nicknamed, has diminished. Nevertheless, the "pacification" policy is strongly contested by many favela residents who emphasise that it has not provided security for them, and that state presence in terms of public services and social programmes is still lacking. In some favelas in the south zone, "pacification" has opened up the area for the establishment of formal businesses and property speculation. 
In other words, the residents of these territories have been "captured" as consumers in the formal economy (Larkins 2015), while gentrification processes have forced many of the original inhabitants to move to more affordable areas. The favelas have thus become increasingly available to non-residents of various kinds, yet "the asphalt" and the privileges it is associated with is not becoming equally available to favela residents. As the outcomes of gentrification processes are not being mitigated by social programmes or other state interventions, it has been suggested that the "pacification" policy is not so much about including favela residents into formal society, as about making these territories available for outside investments (Sørbøe 2013).

Another problem with the "pacification" policy from the point of view of favela residents is that drug trafficking continues despite police presence, and that confrontations between traffickers and police inside favelas remain a problem. There have been numerous reports of police violence and people being killed by the police. While the police usually claim that such incidents are the outcome of confrontations with criminals, video evidence provided by witnesses has shown that often, the versions of events provided by the police are very misleading (Timerman 2014). Indeed, many of those killed by the police turn out to be cases of police aggression, torture, mistaken identity, stray bullets or being caught in the crossfire, yet the responsible officers are rarely charged.

The number of deaths at police hands has remained high throughout the "pacification" process. In 2011, 524 people were killed by the police in Rio de Janeiro State (Prado 2014), and in 2012 the number was 415 (Duarte and Benevides 2013). In 2013, the police were considered responsible for 8.7 per cent of all murders (Benites 2014). Young, AfroBrazilian men make up the majority of Brazilian murder victims (Puff 2014). The fact that a substantial number of them die at police hands in favelas has made critics - citizens, activists, academics and politicianscharacterise this situation, and the public indifference to it, as a "genocide of the black youth" (Puff 2014; Ramos 2012; Duarte 2013) and as a "criminalisation of poverty" (Insurgencia 2014; Vaz 2014). Trust between favela residents and the police is thus frayed. So much so, that in the Alemão complex of favelas, many residents consider that the drug traffickers did a better job at providing security for the community than the police have been doing since "pacification" (Savell 2014). 


\section{Mega-Events and Access to Urban Spaces}

The hosting of mega-events has laid bare that unequal access to urban spaces and territories has not been mitigated, but actually exacerbated during the Pink Tide-era in Rio de Janeiro. Evictions from poor neighbourhoods to make space for event infrastructure, gentrification and property speculation in favelas, the exclusion of street vendors from event venues and a security policy that leave many people feel targeted rather than protected in their own neighbourhoods, all contribute to making life more difficult for Rio's poor. The mega-events play a contradictory role in this scenario, with significant inconsistencies between discourse and reality, projected and actual outcomes. The awarding of the 2016 Olympics to Rio de Janeiro was widely considered a feather in the cap for the Pink Tide president Luiz Inácio Lula da Silva and a chance to showcase the successes of his governments. At the same time, Rio's Olympic bid document emphasised the adaption of the city for business and tourism as one of the main event legacies (Comité de Candidatura Rio 2016 2009). And indeed, the events were approached by local politicians and business owners as a chance to push through controversial decisions that were highly profitable for them, while funding for projected social legacy projects dwindled (Barbassa 2015).

As part of an event-related urban revitalisation, spectacular infrastructure projects were initiated. These include gondolas in the Providência and Complexo do Alemão favelas and the upgrading of Rio's historical port area (the Porto Maravilha project). The Maracanã stadium and the Galeão International Airport were reformed, and three bus rapid transit lines (BRT) connecting the Olympic Park, Deodoro (another Olympic venue) and the airport were constructed. All of these projects are critiqued for primarily adapting Rio for tourism and investment, and not alleviating problems of mobility for residents of the city. The projects are met with resistance from locals because people understand them to be realised at the expense of the provision of clean water, sewerage systems, waste disposal and electricity as well as quality education, health services and security for all residents in the city. The infrastructure projects have also brought with them a high number of forced evictions, and thus serve as an excuse for the city administration to clear attractive areas of poor residents. Indeed, while doing fieldwork in Vila Autódromo, a neighbourhood that was almost decimated during the construction of the Olympic Park (Ystanes 2016a, b), I was constantly reminded of this problematic. Here, there was no need for residents to leave the area in order for the Olympic Park project to be completed, yet, almost all of 
them were evicted with varying degree of force and pressure-most likely to make the area available for future property development. The people in Vila Autódromo considered the Transoeste BRT line, which connects the Olympic venues with Campo Grande, part of this plan. This new connection did little to improve their need for public transport in the area, yet made it more feasible to clear this attractive land of poor people without compromising the middle and upper classes' access to cheap service labour. Campo Grande is located almost 70 kilometres from the centre of Rio de Janeiro, and is a stronghold for paramilitary militias. Many of those forcibly evicted from central areas are re-located there. The new BRT line makes it easier to live in Campo Grande and retain work in the more centrally located areas they were forced to leave. At the same time, local bus lines that made movement within the area surrounding Vila Autódromo possible, were closed down as the BRT lines were introduced. This was phrased as an environmental measure, but the reality for people near the Olympic Park was that it first and foremost made it difficult to operate locally without private cars. The residents of Vila Autódromo therefore saw the BRT Olympic infrastructure project as yet another measure introduced by Rio's city administration to make it as difficult as possible for them to stay in the area.

This is part of a wider process of gentrification and exclusion in the city that was exacerbated by the sporting mega-events. As an Amnesty International representative put it:

There is a process of gentrification taking place in the whole city that is connected to the sports events and how the government sees the city: it is no longer a place for residents, but as a business to sell to foreign investors. That's what the World Cup is about. (Gibson and Watts 2013)

In many ways, the developments brought about by hosting mega-events were counterproductive to the process of making Brazil a more equitable society, and harked back to an authoritarian past. Indeed, Marcelo Freixo (PSOL), state deputy and president of the Human Rights Commission of the Legislative Assembly of Rio de Janeiro sees the many deaths at police hands as a continuity with the military dictatorship:

The enemy of the dictatorship was the communist, the academic, the journalist, who were imprisoned, tortured and killed. Today, there is still this logic of confronting the enemy. Only that today, the enemy is the poor, the one who is superfluous in the market society. We continue to have a security policy based in the idea of war. (Prado 2014) 
Many Brazilians share this view, and are concerned about the direction their country has taken (see e.g. Ystanes 2015). As the digital representations of violence and inequality that arise out of the "pacification" policy illustrate, for many living in Rio's informal neighbourhoods, the situation is indeed experienced as critical. As regards the reproduction of inequality and exclusion through these policies, Gaffney $(2010,27)$ points out that there are significant similarities between how situations of crisis, war and disaster have been used to push through unpopular neoliberal policies (see Klein 2007), and the suspension of ordinary democratic processes to pave the way for mega-events as vehicles for "accelerated development". Spectacular displays of the security apparatus serve as powerful symbols of the degree to which militarisation of public space is integral to these processes (see also Larkins 2015). The high numbers of Military Police in riot-gear at demonstrations, at times appearing to outnumber the protesters, made it clear that opposition could be violently subdued at any moment - and at times it was. As the World Cup was under way, spectators entering and leaving the FIFA Fanfest metro station had to run the gauntlet of heavily armed soldiers and military vehicles, thus receiving a contradictory message of safety blended with mortal danger. The fact that on-going developments are understood by so many as criminalising social movements and poverty - and even as a genocide of the black youth (Duarte 2013; Puff 2014)-further emphasises that mega-events approached as "accelerated development" do not create a fertile ground for enhancing equality and social cohesion. Rather, this approach builds on and reinforces already existing inequalities. An arena where this effect can be clearly observed is the digital representations of it produced by those affected, across different favela communities.

\section{Digital Representations of Violence and Inequality: Subaltern Counterpublics}

Before, during and after the 2014 World Cup and the 2016 Olympics, activists and community journalists based in Rio's favelas have criticised the high levels of violence since "pacification" through social media. Here, they warn residents of on-going gunfights and document events and their experiences of living with this situation. Social media has also been used to rally people to participate in street marches and other events in affected areas. One such event was a peace march in protest of the "pacification" policy, where police violence was thematised and performatively re-enacted. Another was a march 
in favour of preserving the museum of the Maré complex of favelas, which was the outcome of a joint effort amongst collectives from several favelas as well as NGOs. Voz da Comunidade head a campaign distributing gifts and sweets to children in Complexo do Alemão for Christmas and Easter, and document its unfolding on social media. In November 2015, Coletivo Papo Reto organised a protest on the five-year anniversary for the "pacification" of Complexo do Alemão called 5 anos de paciFICÇ $\tilde{A} O$ ( 5 years of paciFICTION). These events were also documented on social media. For example, the paciFICÇÃO event produced numerous posts and photos in social media, and was also followed up with a long blog post on the Coletivo Papo Reto website explaining the reasoning behind the protest. In the main photo accompanying the blog post, one of the Coletivo members is seen holding up a banner in front of a UPP police that reads: Pacificação sem oportunidade e educação é como apagar fogo com gasolina. \#soscpx - 1 (Pacification without opportunities and education is like putting out fire with gasoline). The hashtag \#soscpx (SOS Complexo do Alemão) appearing on a banner in a street protest, which later makes its way onto social media and blogs, where it emerged in the first place, exemplifies Castells' (2015) point that social media activism and real life activism are inseparable. They feed each other rather than constitute different domains.

Running through the digital representations of violence and inequality are slogans and hashtags asking for peace and shouting SOS on behalf of their crisis-ridden communities (e.g \#FavelaPedePaz (favela asks for peace), \#sosfavela). The language applied in this activism emphasises the message that the pacification has thrown these communities into crisis rather than resolved their security problems. An example of this is the \#100diasSEMpaz (\#100daysWITHOUTpeace) hashtag that arose in the Alemão complex of favelas in the beginning of 2015 after 100 consecutive days of gunfire, in which residents, including a child, lost their lives.

Another social media campaign called "Eu não mereço morrer assassinado" (I do not deserve to be assassinated), got considerable attention in April 2014. It arose after Douglas Rafael da Silva Pereira, a 26-year-old dancer, was killed by the police in a "pacified" favela above Copacabana, and made explicit links between Afro-Brazilian ancestry and the risk of falling victim to police violence. The campaign thus denounced racism and the unequal value placed on human lives, both by the police and the wider public. It also emphasised their experience that the right to feel safe 
remains a privilege reserved for the generally lighter skinned inhabitants of middle-class neighbourhoods.

Shootouts taking place within the "pacified" favelas are often documented in videos uploaded to Facebook. Normally, these videos are filmed with mobile phone cameras through a window or from a rooftop. The visual contents serve to locate the event in a favela; what we see is usually a dark, empty alleyway with the typical several-storey brick houses. The soundtrack is the main feature of the videos and consists of the sound of intense gunfire. The captions accompanying such videos sometimes express rage at the situation in which the community finds itself and at the "pacification" policy. The disadvantaged position of favela residents in Rio's social landscape is sometimes also pointed out, either in the captions or in the comment sections. At other times, the caption simply warns: Muitos tiros hoje! (Much gunfire today!), and mentions the community or the specific location it takes place so that people can be informed and stay away.

The residents in Vila Autódromo, who fought forced evictions as the Olympic Park was built next to their neighbourhood, also used social media to organise events and protest, and to connect with an international public. Via Whatsapp groups for activists and journalists they swiftly managed to get the attention of supporters and international correspondents whenever a house was in risk of being demolished. They also organised cultural protest events, using social media tools to disseminate information about them both before and after. Showing a keen awareness of the power of image and alternative media, as they called it, the residents also wrote on the houses' outer walls to present their analysis of what was happening to their neighbourhood. "Sometimes when journalists come bere there is nobody available to talk to them, so we write on the walls so that they can do the talking”, one of them explained (Photo 4.2).

Following Fraser (Fraser 1990), I take the social media representations of violence and inequality arising out of affected communities to constitute subaltern counterpublics. Subaltern counterpublics are defined as

parallel discursive arenas where members of subordinated social groups invent and circulate counterdiscourses, which in turn permit them to formulate oppositional interpretations of their identities, interests, and needs. (Fraser 1990, 67) 


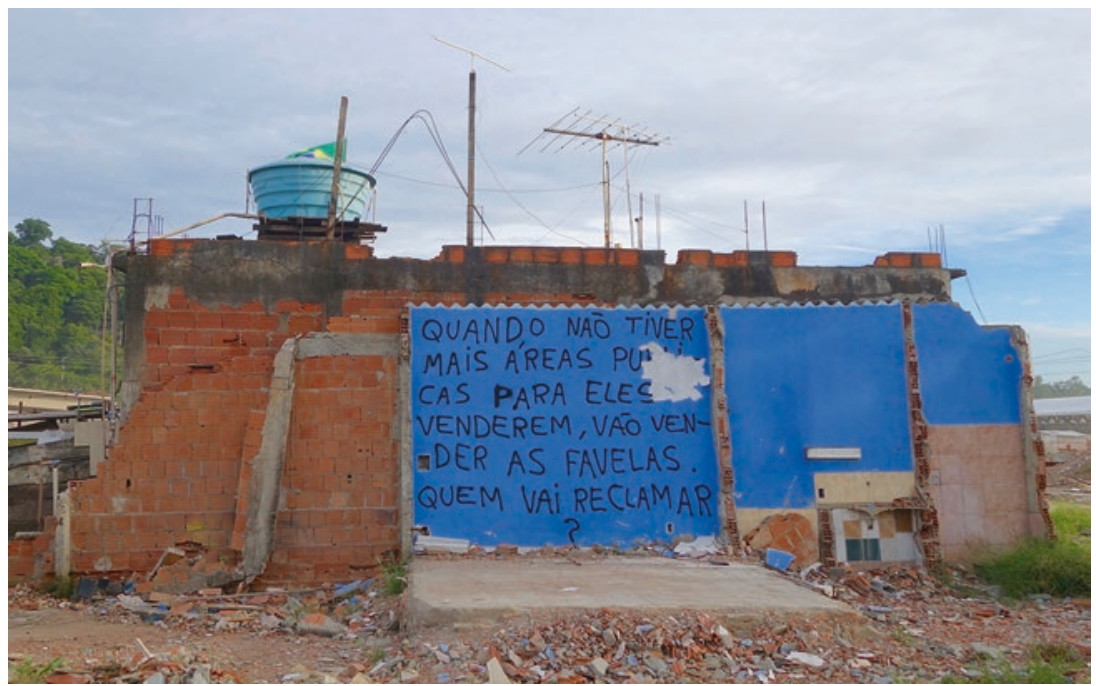

Photo 4.2 Graffiti in Vila Autódromo shows that the residents consider the confiscation of their neighbourhood as a transfer of public land to private actors: "When there are no more public areas to sell, they will sell the favelas. Who will protest?” (Photo: Margit Ystanes)

An example of such a subaltern counterpublic, Fraser states, is the latetwentieth century US feminist discursive arena. Here, new terms for describing reality have been invented, such as "sexism", "double shift", "sexual harassment", "date rape" and so on. Gradually, these terms have made their way into debates beyond feminist circles, where they are both accepted and critiqued. This illustrates the potential of subaltern counterpublics to contribute to deliberations and contestations in other arenas. According to Fraser, subaltern counterpublics have a dual character in stratified societies. They function as spaces of withdrawal and regroupment, and simultaneously, as bases and training grounds for agitational activities directed towards wider publics. In this dialectic lies their emancipatory potential; the ability to somewhat offset the unjust participatory privileges enjoyed by the members of dominant social groups (Fraser $1990,68)$.

It is of course an empirical question to be explored in each case to what extent subaltern counterpublics are separate from other publics. Fraser argues that insofar as these arenas are indeed publics, they are by definition 
not enclaves, although they can be involuntarily enclaved (Fraser 1990, 67). The online resources used to distribute the representations of violence and inequality discussed here arguably constitute a public. Facebook's "fan pages", Twitter accounts, YouTube, blogs and other websites are open and available to anyone with an Internet connection. Even personal Facebook pages are considered public, as many politicians and other public figures have learned upon posting controversial updates and being taken to task for it "in real life". Whatsapp, a messenger app that is hugely popular in Rio's favelas, constitutes a semi-public arena. The app allows for making large groups of users who can quickly disseminate information to one another through a single message, which may include photos, video or sound recordings. Because of this, activists I spoke to consider that Whatsapp plays a crucial role in creating consciousness and for mobilising around particular issues. For example, the establishment of a Whatsapp group including residents from all over Complexo do Alemão created awareness of the scale of shootouts in this vast area. As group members from different favelas within the complex shared information about their particular neighbourhood, this provided the impetus for the \#100diasSEMpaz campaign discussed above.

A study from 2013 showed that 52 per cent of favela residents in Brazil has access to the Internet (Caldeiro 2013). A considerable number of those living in favelas, then, may potentially participate in the digital dissemination, consumption and debate about experiences of violence and inequality.

Perhaps because of the connection between the injustices they are protesting and the mega-events, the activities of Coletivo Papo Reto and others have caught the interest of international media. The Coletivo, for example, have been the subject of a New York Times article (Shaer 2015) and an $\mathrm{Al}$ Jazeera documentary. They cooperate with international activists, and in 2015 they received Brazil Foundation's annual International Philanthropy Award in New York. The tribulations of residents in Vila Autódromo have been documented by numerous international media outlets, e.g. The Guardian, Time, The Nation, USA Today, ESPN, New York Times, The Independent, LA Times, Al Jazeera, ROAR Magazine, to mention a few. The "Eu não mereço morrer assassinado" campaign was reported about on brasilpost.com.br, a Huffington Post site dedicated to news from Brazil in Portuguese (Thanyá 2014). Coletivo Papo Reto's Facebook page and others like it, are sometimes used as sources in the reporting of other alternative media, e.g. Jornal a Nova 
Democracia, which exist both as a printed newspaper, a YouTube channel, a website and a Facebook site.

The digital representations of violence and inequality in question here are nevertheless quite excluded from Brazilian mass media narratives. As mentioned above, mass media in Brazil constitutes a relatively homogeneous sphere dominated by the Globo Media Group and the representation of middle- and upper-class worldviews. A member of the Coletivo Papo Reto told me, "when the New York Times did a story on us, the Brazilian media did a story on the story, but not on us". Even so, some of these narratives do seep into other publics, and it is increasingly problematic to claim that they are completely enclaved. If we follow Fraser (1990), the work of these community activists can therefore be considered an important expansion of the public sphere of deliberation and contestation in Brazil. While their transformative potential with regards to influencing mainstream public debate and media remains to be seen, it is clear that a subaltern counterpublic has been established. At the moment, this counterpublic appears to function both as a community service providing crucial information, but also as a laboratory where approaches to representation and empowerment are being tested and refined. Increasingly, this subaltern counterpublic is being recognised by an international public.

The mega-events that sparked this activism in Rio are now over, but the struggle over the access to and management of urban spaces and territories is not. As the current Brazilian government threatens to reverse many of the gains towards equality achieved during the Pink Tide, this struggle continues on the platforms established by journalists-as-activists in recent years. Indeed, the methodology and infrastructure for protest and activism based on social media and mobile technology is one of the most significant legacies of the 2014 World Cup and the 2016 Olympics.

\section{Concluding Thoughts}

As the Brazilian Pink Tide now recedes, the country is in economic crisis and the Worker Party's president Dilma Rousseff was removed by a questionable impeachment process in August 2016. ${ }^{5}$ The current right-wing government of Michel Temer has since introduced austerity politics that threaten to reverse many of the gains towards a more equal Brazil achieved during the last couple of decades. Nevertheless, prior to these developments Brazil made significant gains in the inclusion of the formerly excluded by raising the minimum wages, introducing the conditional cash 
transfer programme Bolsa Familia (see de Lavra Pinta (Chap. 6), this volume), as well as quotas for Afro-Brazilians in prestigious public universities. All of this was helped along by impressive economic growth. Nevertheless, these policies have not been sufficient to eradicate poverty and erase the conceptual and social distinction between favela and "the asphalt", the formal neighbourhoods.

As the reconfiguration of public spaces ushered in by the hosting of mega-events made clear, nor did the Pink Tide reduce historical inequalities with regards to access to these spaces. If anything, the eviction and security policies of recent years did much to reverse any gains by clearing out poor people from attractive areas (Ystanes 2016a, b; de Magalhães 2013; Rolnik 2015; Barbassa 2015). Militarising the spaces where poor people live either officially through "pacification" (Salem 2016; Larkins 2015; Sørbøe 2013) or unofficially through paramilitary militias (Vieira 2016; Martín 2016), was equally destructive for residents. It is interesting in this regard that when the army occupies a favela as part of the "pacification" process they claim the territory by planting the Brazilian flag there. This symbolic gesture illustrates the extent to which favelas are considered external to the rest of Brazil. The high incidence of police violence and deaths at police hands in "pacified" favelas, as well as the apparent acceptance of this reality by the rest of the population, further emphasises the unequal value placed on human lives.

When the Olympics kicked off in August 2016, the city had been in mega-event preparation mode ever since it was awarded the Pan American Games in 2002. This was the same year the Labour Party candidate Luiz Inácio Lula da Silva was elected president and the processes referred to as the Pink Tide were most actively set in motion in Brazil. These parallel and in many ways incompatible developments are informative. The deepening inequalities arising from the reconfigurations of urban spaces as preparations for the mega-events reveal the shallowness of the reforms of the Pink Tide. While significant gains were made with regard to identity politics as well as economic inequality, the clearing out of poor and Afro-descendant residents from attractive areas as the city prepared for the mega-events spoke volumes about the challenges still ahead for those who desire a more equal Brazil. Mass media's lack of interest in the fate of those who are adversely affected by these developments, further emphasise that inequality is not just inscribed in the urban landscape, but also in the lifeworlds of those who inhabit this landscape. 
The rise of journalism-as-activism constitutes a challenge to these structures. By weaving together digital and "real life" events, this is not merely the production of a discourse where the most educationally privileged and politically conscious favela residents participate. It facilitates and informs about activities and events that are firmly located within local communities, and reaches and includes people who are not present on social media. Indeed, these practices, digital and "in real life", contribute to widening the sphere of public contestation, and provide virtual and local spaces where stories about violence, inequality and exclusion can be told. As such, digital community journalism can potentially help erode the exclusionary modes of public debate that currently dominate Brazilian mass media and challenge persistent inequality.

Acknowledgements Earlier versions of this text have been presented at the original workshop organised in Bergen, at the 2015 LASA (Latin American Studies Association) congress in San José and at the ESPM (Escola Superior de Propaganda e Marketing) in Rio de Janeiro. I am grateful to all of those who participated in these events for their comments, and to Michele de Lavra Pinto for the invitation to speak at ESPM. Alejandro Huidobro Goya and Iselin Åsedotter Strønen also read and commented upon different draft versions. I extend my most heartfelt gratitude to all these keen readers and listeners, who contributed significantly to improving the text. The Research Council of Norway's SAMKUL programme (Cultural conditions underlying social change) generously funded the research project this chapter grew out of.

\section{Notes}

1. In Portuguese: “...falaram que era bandido mas morreu mais um inocente, aqui tem trabalhador e também tem estudante mas pra eles se tá no morro tu já é traficante".

2. The drawing can be seen here: https://tinyurl.com/lwhpcqa.

3. Alemão and Maré are names of large favela complexes, whereas Rocinha is the name of Rio's largest favela. Voz da Comunidade means "voice of the community". Comunidade (community) is an often-used term for favela that was originally intended to escape the stigma associated with being a favela resident. In Rio, however, most social media activists use the term "favela", and focus on challenging the injustices suffered by the residents of these places and cultivating a positive self-image through the use of music, art and other cultural expressions. The title Voz da Comunidade thus plays on the idea that the purpose of this news outlet is to give voice to favela residents. 
4. Although it must be added that later Habermas modified this view.

5. See the Introduction, as well as Costa's (Chap. 3) and Sørbøe's (Chap. 5 ) in this book, for more on the impeachment of Dilma Rousseff.

\section{REFERENCES}

Barbassa, Juliana. 2015. Dancing with the Devil in the City of God: Rio de Janeiro on the Brink. New York: Touchstone.

Benites, Afonso. 2014. Polícia Brasileira Mata Cinco Pessoas a Cada Dia. El País. https://tinyurl.com/lv6ew43

Boykoff, Jules. 2016. Power Games: A Political History of the Olympics. London/ New York: Verso.

Brasil, Luisa. 2015. Empregadores Domésticos Rejeitam Morador de Favela. $O$ Dia. http://odia.ig.com.br/noticia/economia/2015-02-12/empregadoresdomesticos-rejeitam-morador-de-favela.html

Brito, Guilherme. 2014. Sininho E Outros Ativistas Suspeitos de Atos Violentos, No Rio, São Detidos. O Globo. http://gl.globo.com/rio-de-janeiro/noticia/2014/07/ativistas-suspeitos-de-atos-violentos-em-protestos-sao-detidosno-rio.html

Caldeira, Teresa Pires do Rio. 1988. The Art of Being Indirect: Talking About Politics in Brazil. Cultural Anthropology 3 (4): 444-454.

Caldeiro, João Pedro. 2013. 65\% Dos Moradores de Favelas No Brasil São de Classe Média. Exame. http://exame.abril.com.br/economia/ noticias /65-dos-moradores-de-favela-sao-de-classe-media

Castells, Manuel. 2015. Networks of Outrage and Hope: Social Movements in the Internet Age. Cambridge/Malden: Polity Press.

Coelho, Janet Tappin. 2016. Rio de Janeiro Citizens to Receive New App to Record Police Violence in City's Favelas. The Independent. https://tinyurl. com/kdhc4uf

Comité de Candidatura Rio 2016. 2009. Rio de Janeiro 2016. Dossiê de Candidatura Do Rio de Janeiro a Sede Dos Jogos Olimpicos E Paraolímpicos de 2016. http://www. rio2016.com/sites/default/files/parceiros/dossie_de_candidatura_vl.pdf

Cornelissen, Scarlett. 2012. 'Our Struggles Are Bigger than the World Cup': Civic Activism, State-Society Relations and the Socio-Political Legacies of the 2010 World Cup. British Journal of Sociology 63 (2): 328-248.

Deak, Andre. 2014. Apagão Na Democracia. Brasil Post. http://www.brasilpost. com.br/andre-deak/apagao-na-democracia_b_5581013.html

de Magalhães, Alexandre Almeida. 2013. Transformações No 'problema Favela' E a Reatualização Da 'remoção' No Rio de Janeiro. Universidade do Estado do Rio de Janeiro. 
Duarte, Rachel. 2013. Juventude Brasileira Grita Contra Genocídio de Jovens Negros. Sul21. http://www.sul21.com.br/jornal/ juventude-brasileira-grita-contra-genocidio-de-jovens-negros-no-brasil/

Duarte, Alssandra, and Carolina Benevides. 2013. Polícia Mata Cinco Pessoas Por Dia No Brasil. O Globo, November 3. https://tinyurl.com/kvmmgk7

Fraser, Nancy. 1990. Rethinking the Public Sphere: A Contribution to the Critique of Actually Existing Democracy. Social Text (25/26): 56-80.

Gaffney, Christopher. 2010. Mega-Events and Socio-Spatial Dynamics in Rio de Janeiro, 1919-2016. Journal of Latin American Geography 9 (1): 7-29.

—_. 2014. Global Parties, Galactic Hangovers: Brazil's Mega Event Dystopia. Los Angeles Review of Books. https://lareviewofbooks.org/essay/ global-parties-galactic-hangovers-brazils-mega-event-dystopia

Gibson, Owen, and Jonathan Watts. 2013. World Cup: Rio Favelas Being 'Socially Cleansed' in Runup to Sporting Events. The Guardian. http://www.theguardian.com/world/2013/dec/05/world-cup-favelas-socially-cleansed-olympics

Glenny, Misha. 2016. Nemesis: One Man and the Battle for Rio. New York: Alfred A. Knopf.

Green, Maia. 2003. Globalizing Development in Tanzania. Policy Franchising Through Participatory Project Management. Critique of Anthropology 23 (2): $123-143$.

Habermas, Jürgen. 1991. The Structural Transformation of the Public Sphere: An Inquiry into a Category of Bourgeois Society. Cambridge, MA: MIT Press.

Inman, Phillip. 2012. Brazil's Economy Overtakes UK to Become World's Sixth Largest. The Guardian. http://www.guardian.co.uk/business/2012/mar/06/ brazil-economy-worlds-sixth-largest

Insurgencia. 2014. Drogas, UPP E Criminalização Da Pobreza Em Debate. Insurgencia. Tendência Interna Do PSOL. http://www.insurgencia.org/ drogas-upp-e-criminalizacao-da-pobreza-em-debate/

Klein, Naomi. 2007. The Shock Doctrine: The Rise of Disaster Capitalism. London/ New York: Penguin.

Larkins, Erika Mary Robb. 2015. The Spectacular Favela: Violence in Modern Brazil. Oakland: University of California Press.

Martín, Maria. 2016. Como a Milícia Se Infiltrou Na Vida Do Rio. El Pais. http:// brasil.elpais.com/brasil/2016/07/21/politica/1469054817_355385. html? rel=mas

Ng'weno, Bettina. 2007. Turf Wars. Territory and Citizenship in the Contemporary State. Stanford: Stanford University Press.

Nunes, Rodrigo. 2014. The Worst Kind of World Cup Legacy: Brazil's New Political Prisoners. Huffington Post. http://www.huffingtonpost.com/rodrigo-nunes/ the-worst-kind-of-world-c_b_5620976.html

Olsen, Maren Næss. 2012. Verden i Krise, Brasil På Ferie. Morgenbladet. http:// morgenbladet.no/samfunn/2012/verden_i_krise_brasil_pa_ferie 
Pearlman, Janice. 2010. Favela. Four Decades of Living on the Edge in Rio de Janeiro. Oxford: Oxford University Press.

Prado, Raphael. 2014. PM Do Rio E de SP Mata Mais Que Todos Os Países Com Pena de Morte Somados. Folhapolitica.org, January 8. https://tinyurl.com/ $\mathrm{m} 6 \mathrm{n} 2 \mathrm{~d} 2 \mathrm{~b}$

Puff, Jefferson. 2014. 'Genocídio' de Jovens Negros É Alvo de Nova Campanha Da Anistia No Brasil. BBC. http://www.bbc.co.uk/portuguese/ noticias/2014/11/141108_genocidio_jovens_negros_anistia_jp_rb

Ramos, Paulo. 2012. A Violência Contra Jovens Negros No Brasil. Carta Capital. http://www.cartacapital.com.br/sociedade/a-violencia-contra-jovens-negrosno-brasil/

Rolnik, Raquel. 2015. Guerra Dos Lugares: A Colonização Da Terra E Da Moradia Na Era Das Finanças. São Paulo: Boitempo Editorial.

Salem, Tomas. 2016. Taming the War Machine: Police, Pacification and Power in Rio de Janeiro. Thesis Submitted for the MA Degree at Department of Social Anthropology, University of Bergen.

Savell, Stephanie. 2014. The Brazilian Military, Public Security, and Rio de Janeiro's 'Pacification.' Anthropoliteia.net.

Sawyer, Suzana. 2003. Subterranean Techniques. Corporate Environmentalism, Oil Operations, and Social Injustice in the Ecuadorian Rain Forest. In In Search of the Rain Forest, ed. Candace Slater, 69-100. Durham/London: Duke University Press.

Shaer, Matthew. 2015. 'The Media Doesn't Care What Happens Here'. The New York Times Magazine. http://tinyurl.com/ora26mr

Sørbøe, Celina Myrann. 2013. Security and Inclusive Citizenship in the Mega-City. The Pacification of Rocinba, Rio de Janeiro. Thesis Submitted for the MA Degree at Department of Literature, Area Studies and European Languages, University of Oslo.

Stepan, Nancy Leys. 1991. 'The Hour of Eugenics'. Race, Gender, and Nation in Latin America. Ithaca/London: Cornell University Press.

Thanyá, Yasmin. 2014. Eu Não Mereço Morrer Assassinado. Brasilpost.com.br, April 24. http://tinyurl.com/llubhhy

Timerman, Jordana. 2014. In Brazil, Where Police Killings Are Commonplace, Cell Phone Cameras Play a Powerful Role. The Atlantic/Citylab. https:// tinyurl.com/mmxpg2o

Tsavkko Garcia, Raphael. 2014. Dozens of Activists in Brazil Were Arrested Not for Protesting the World Cup, but for Possibly Planning to Do So. Global Voices. http://globalvoicesonline.org/2014/07/22/ brazil-preemptively-arrests-activists-before-world-cup-final/

Vaz, Thiago. 2014. Criminalização Da Pobreza E Violência Do Estado. Observatório Da Imprensa. http://www.observatoriodaimprensa.com.br/ news/view/_ed794_criminalizacao_da_pobreza_e_violencia_do_estado

Vieira, André. 2016. 'Milícia É Sempre Governo, Nunca Oposição', Diz Freixo. Brasil de Fato. 
Ystanes, Margit. 2011. Precarious Trust. Problems of Managing Self and Sociality in Guatemala. Dissertation Submitted for the Degree of Philosophiae Doctor $(\mathrm{PhD})$ at the University of Bergen.

- 2014. Saving Guatemala's 'Mayan Forest': The Environmental Crisis and Contested Development. In Crisis in the Nordic Nations and Beyond: At the Intersection of Environment, Finance and Multiculturalism, ed. Kristín Loftsdóttir and Lars Jensen, 121-142. Farnham: Ashgate.

- 2015. 'Problemet Er at vi Ikke Aner Hvor Dette Bærer': Dystopiske Fremtidsforestillinger i Sportsarrangementenes Tid. Norsh Antropologisk Tidsskrift (3/4): 221-239.

_ 2016a. Brasils Problematiske OL-Arv. Manifest Tidsskrift.

- 2016b. Mega-Events and Urban Poverty: Legacy Projects in Rio de Janeiro. CROP Poverty Brief (31), April.

Open Access This chapter is licensed under the terms of the Creative Commons Attribution 4.0 International License (http://creativecommons.org/licenses/ by $/ 4.0 /)$, which permits use, sharing, adaptation, distribution and reproduction in any medium or format, as long as you give appropriate credit to the original author(s) and the source, provide a link to the Creative Commons license and indicate if changes were made.

The images or other third party material in this chapter are included in the chapter's Creative Commons license, unless indicated otherwise in a credit line to the material. If material is not included in the chapter's Creative Commons license and your intended use is not permitted by statutory regulation or exceeds the permitted use, you will need to obtain permission directly from the copyright holder.

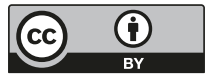

